\title{
Pendekatan E-Budgeting Untuk Pemantauan Anggaran Perjalanan Dinas
}

\author{
M. Yoga Distra Sudirman ${ }^{1}$; Dine Tiara Kusuma ${ }^{2}$; Yessy Fitriani ${ }^{3}$ \\ 1, 2, 3 Institut Teknologi PLN \\ ${ }^{1}$ yogadistra@itpln.ac.id
}

\begin{abstract}
Outcomes-Based Budgeting (OBB) is a strategic management tool designed under the Strategic Reform Initiative (SRI). There are 5 processes in the $O B B$, namely planning for outcome, budgeting for outcome, program implementation, monitoring and evaluation, as well as policies and program improvements. In this study the OBB process will be implemented into a system that regulates official travel. This application development method is extreme programming with 4 stages, namely planning, design, coding and testing. The results obtained are the OBB framework can be implemented into duty travel system. Cycle of 5 process at OBB are able to run well in the officials travel budgeting system. The conclusion of this study is that the OBB framework provides information to top level officials in monitoring and evaluating the process and results of official travel that are being or have been carried out. In addition, top level officials can monitor the remaining budget on the budgeted officials travel budget.
\end{abstract}

Keywords: information systems, e-budgeting, duty travel, outcome based budgeting, monitoring

\begin{abstract}
ABSTRAK
Penganggaran Berbasis Hasil (OBB) adalah alat manajemen strategis yang dirancang di bawah Inisiatif Reformasi Strategis (SRI). Terdapat 5 proses pada OBB yaitu perencanaan pengeluaran, penganggaran pengeluaran, implementasi program, monitoring dan evaluasi, serta kebijakan dan perbaikan. Pada penelitian ini akan diimplementasikan proses OBB kedalam sistem yang mengatur perjalanan dinas. Metode pengembangan aplikasi ini menggunakan extreme programming dengan 4 tahapan yakni perencanaan, perancangan, pengkodean dan pengujian. Hasil yang didapatkan adalah kerangka OBB dapat dimasukkan kedalam sebuah sistem. Siklus 5 proses pada OBB mampu berjalan dengan baik di sistem penganggaran perjalanan dinas. Kesimpulan dari penelitian ini adalah kerangka OBB menyediakan informasi kepada pejabat pemberi perintah dalam memantau dan mengevaluasi proses dan hasil perjalanan dinas yang sedang atau selesai dilaksanakan. Selain itu pejabat pemberi perintah dapat memantau anggaran yang tersisa pada anggaran perjalanan dinas yang telah dianggarkan.
\end{abstract}

Kata kunci: sistem informasi, e-budgeting, perjalanan dinas, penganggaran berbasis hasil, pemantauan 


\section{PENDAHULUAN}

Perjalanan Dinas adalah perjalanan yang dilakukan oleh seorang karyawan atau pegawai suatu lembaga atau perusahaan yang berkaitan dengan tugas pekerjaan.[1] Sebuah pekerjaan yang dilakukan dapat berbagai macam bentuk, namun fokus pada penelitian ini bukan pada manajemen perjalanan dinas. Berikut ini merupakan beberapa penelitian yang melatarbelakangi penelitian ini. Adapun permasalahannya adalah sebagai berikut: [2] [3] [4] [5]

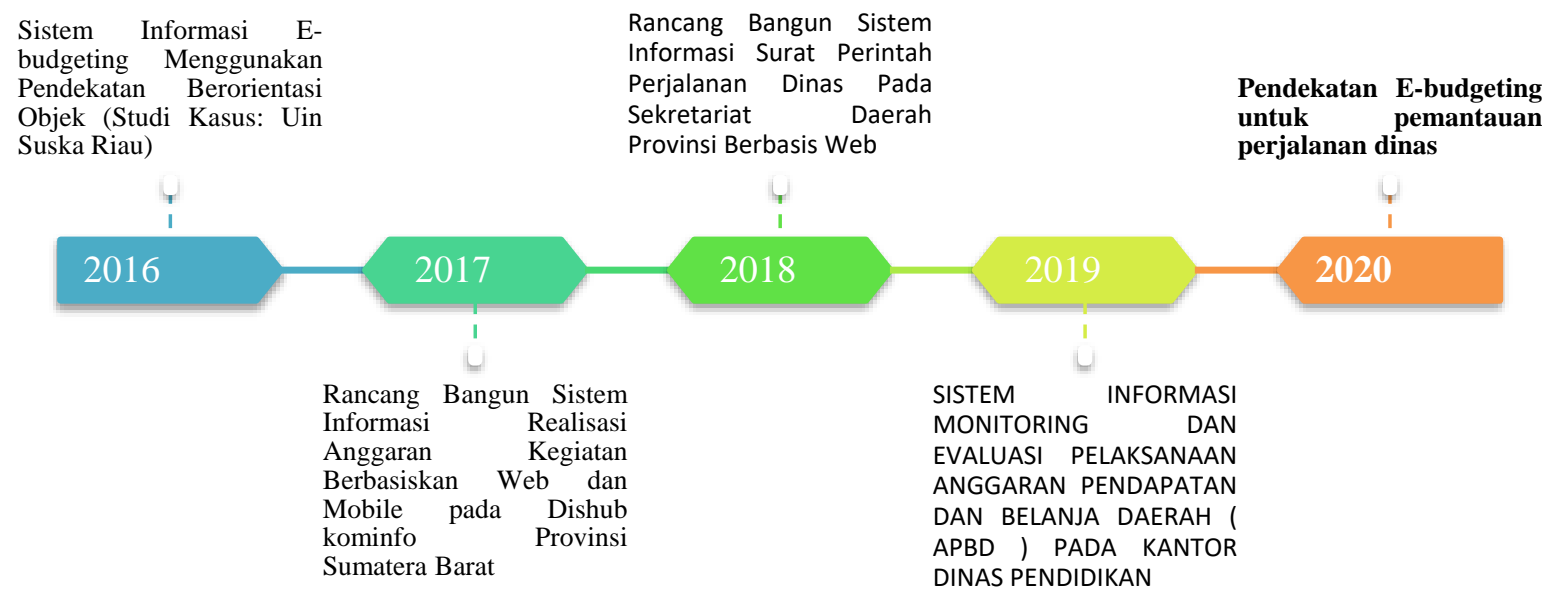

Gambar 1. Analisis permasalahan penelitian

E-Budgeting merupakan subset dari pemerintahan elektronik (e-government) yang menggunakan aplikasi program komputer untuk memfasilitasi proses penyusunan anggaran belanja daerah. salah satu kerangka yang digunakan dalam mengendalikan anggaran tersebut yaitu kerangka Penganggran Berbasis Hasil atau Outcome Based Budgeting.

Penganggaran Berbasis Hasil (OBB) adalah alat manajemen strategis yang dirancang di bawah Inisiatif Reformasi Strategis (SRI). Terdapat 5 proses pada OBB yaitu perencanaan pengeluaran, penganggaran pengeluaran, implementasi program, monitoring dan evaluasi, serta kebijakan dan perbaikan. Pada penelitian ini akan diimplementasikan proses OBB kedalam sistem yang mengatur perjalanan dinas.

Penelitian ini juga sesuai dengan Peraturan Pemerintah Republik Indonesia Nomor 12 tahun 2019 tentang Pengelolaan Keuangan Daerah mengatur keuangan daerah harus tertib, sesuai dengan peraturan perundang-undangan, efisien, ekonomis, efektif, transparan, dan bertanggung jawab dengan memperhatikan keadilan, kepatutan, dan manfaat untuk masyarakat.[6] namun pada penelitian hanya akan membahas penerapan kerangka OBB pada aplikasi perjalanan dinas dimana aplikasi tersebut akan mengikuti kerangka pada OBB dan akan membuat semua aktivitas perjalanan dinas dapat terlaksana terencana, transparan, terarah, terukur dan terjamin dari kualitas informasinya.

\section{METODE / PERANCANGAN PENELITIAN}

\subsection{E-budgeting}

Penggunaan e-Budgeting dapat meringkas proses-proses yang ada seperti menyiapkan data standar harga satuan, pembagian bagian anggaran, memeriksa sumbangan-konsultasi kegiatan, memeriksa anggarannya oleh masing-masing unit kerja, pembahasan internal maupun dengan DPRD, dan kemudian mencari satu kali atau lebih Revisi dikembangkanlah suatu rencana anggaran yang dapat diterima oleh semua pihak dan dapat ditunjukkan Arah Pembangunan.[7] 


\subsection{Anggaran}

Keberhasilan suatu kegiatan dalam pencapaian tujuannya yang efisien dan efektif ditentukan oleh adanya perencanaan yang matang, organisasi yang tepat, serta pengelolaan yang baik. Sebelum membahas tentang anggaran secara mendalam, penulis terlebih dahulu akan mengemukakan pengertian anggaran itu sendiri. "Anggaran yaitu suatu rencana yang disusun secara sistematis yang meliputi seluruh kegiatan perusahaan yang dinyatakan dalam unit kesatuan moneter yang berlaku untuk jangka periode tertentu yang akan datang"'[8].

Rencana yang disusun sangat berdampak terhadap hasil atau tingkat penyerapan dari anggaran. Perencanaan anggaran, pelaksanaan anggaran,dan kompetensi sumber daya manusia berpengaruh terhadap tingkat penyerapan anggaran. Variabel pencatatan administrasi tidak berpengaruh terhadap tingkat penyerapan anggaran.[9]

\subsection{Perjalanan Dinas}

Perjalanan Dinas adalah perjalanan yang dilakukan oleh seorang karyawan atau pegawai suatu lembaga atau perusahaan yang berkaitan dengan tugas pekerjaan kedinasan.[10] Tugas pekerjaan kedinasan adalah tugas pekerjaan yang berkaitandengan kepentingan lembaga atau perusahaan yang bersangkutan".[1] Tugas yang diberikan ini dapat berupa berbagai macam kegiatan diluar kantor atau institusi. Kegiatan perjalanan dinas biasanya dilakukan atas dasar program yang telah direncanakan sebelumnya. Perjalanan dinas memerlukan memperhatikan harus memeperhatikan beberapa prinsip sebagai berikut [6]:

1. selektif, yaitu hanya untuk kepentingan yang sangat tinggi dan prioritas yang berkaitan dengan penyelenggaraan pemerintahan;

2. ketersediaan anggaran dan kesesuaian dengan pencapaian kinerja Kementerian Negara/Lembaga;

3. efisiensi penggunaan belanja negara; dan

4. akuntabilitas pemberian perintah pelaksanaan Perjalanan Dinas dan pembebanan biaya Perjalanan Dinas.

Perjalanan dinas juga tidak dapat dilakukan apabila pelaksana tidak mendapatkan surat tugas pejabat yang berwenang. Semua peraturan perjalanan dinas negara sudah diatur pada Peraturan Menteri Keuangan Republik Indonesia nomor 113/PMK.05/2012 tentang perjalanan dinas dalam negeri bagi Pejabat Negara, Pegawai Negeri dan Pegawai Tidak Tetap.

\subsection{Outcome Based Budgeting (OBB)}

OBB mengubah cara pemerintah membuat keputusan anggaran, dan lembaga-lembaga mengelola sumber dayanya, adalah reformasi mendasar. Untuk memastikan keberhasilan reformasi, transisi akan bertahap selama beberapa tahun, memberikan waktu bagi model untuk berkembang dan matang, dan bagi sektor untuk mengembangkan sistem, proses dan kemampuan yang diperlukan untuk mendukung dan mempertahankan Outcome Budgeting dalam jangka panjang.[11] Berikut merupakan kerangka OBB dari NSW government : 


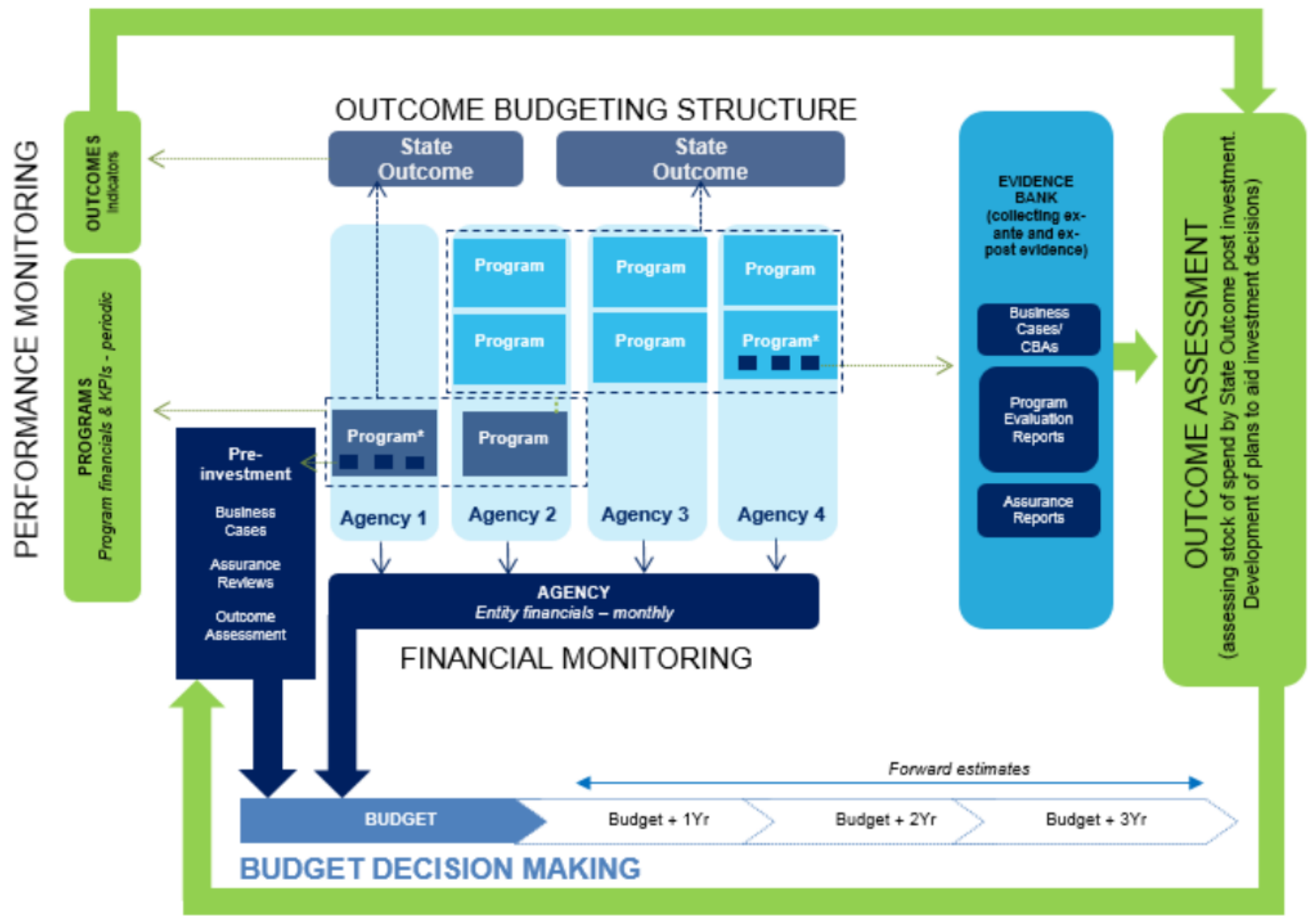

Gambar 2. NSW government Outcome Based Budgeting Framework

Pada gambar 2 dilihat terdapat 4 element penting seperti Outcome Budgeting Structure, Financial and non-financial performance monitoring, Outcomes Assessment, serta Budget decision making. Proses-proses besar seperti gambar 2 akan disederhanakan untuk dikolaborasikan kedalam sebuah aplikasi yang terlihat lebih mudah digunakan.

\subsection{Matrix CRUD}

Matriks CRUD (Create, Read, Update, Delete) adalah cara yang populer untuk menentukan hubungan antara fungsionalitas sistem perangkat lunak dan kelas data. [12]CRUD merupakan salah satu inti dari sebuah pemrograman karena di dalam suatu program biasanya mencakup operasi Create atau menciptakan data, Read atau menampilkan data, Update atau mengedit suatu data dan Delete atau menghapus data.

\subsection{Perancangan Penelitian}

Tahapan penelitian ini akan dikemukakan menggunakan mind map. Terdapat 6 tahapan besar dalam penelitian ini. Adapun tahapan tersebut adalah sebagai berikut: 


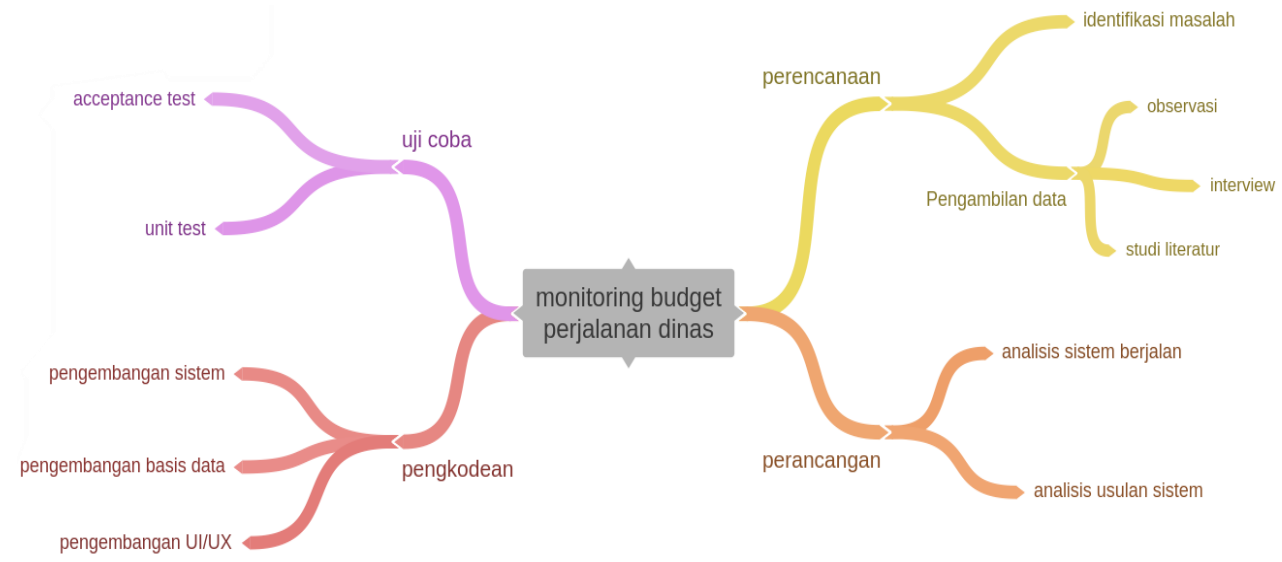

Gambar 3. kerangka berifikir

\section{HASIL DAN PEMBAHASAN}

\subsection{Hasil rancangan $\mathrm{OBB}$}

Rancangan OBB yang digunakan adalah pendekatan yang telah dilakukan penelitian sebelumnya oleh NSW menjadi seperti gambar 4 sebagai berikut :[13]

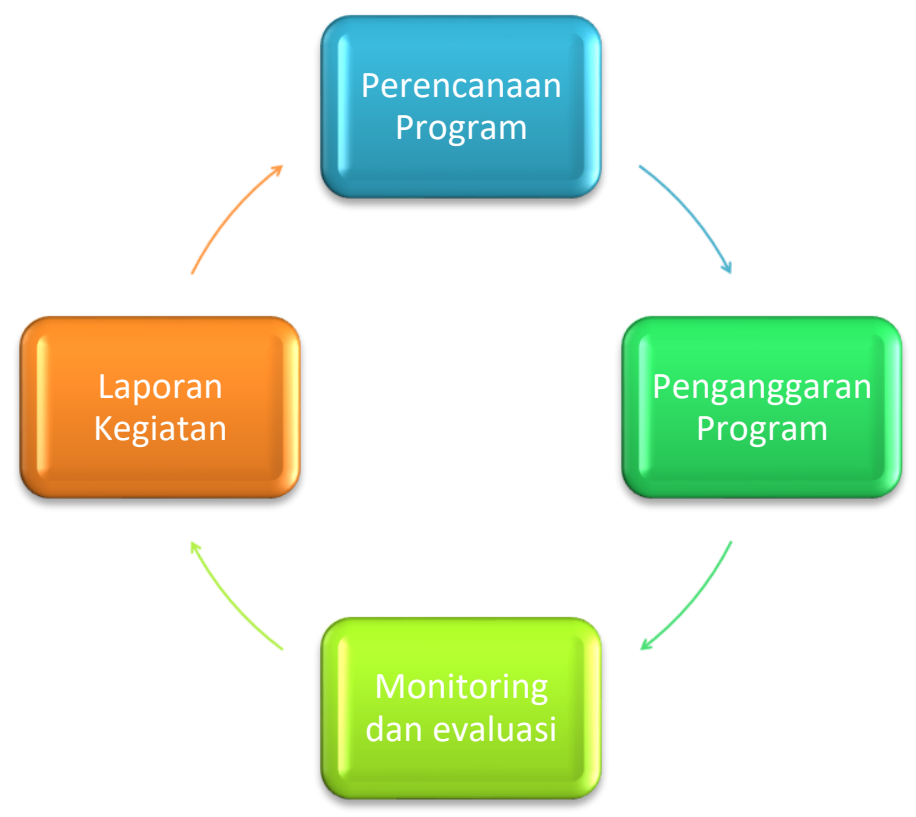

Gambar 4. Kerangka OBB hasil Penyederhanaan model gambar 2

\subsection{Hasil CRUD Matrix}

Adapun tugas dan fungsi entitas tersebut dalam penerapan framework OBB pada aplikasi perjalanan dinas dapat dilihat pada tabel 1 sebagai berikut.

Tabel 1. Rancangan CRUD Matrix Aplikasi

\begin{tabular}{|c|c|c|c|c|c|c|c|c|c|c|}
\hline \multirow{2}{*}{ No } & \multirow{2}{*}{ Fitur } & \multicolumn{3}{|c|}{ Asdep (A) } & \multicolumn{3}{|c|}{ Staff $(\mathbf{O})$} & \multicolumn{3}{|c|}{ Deputi(E) } \\
\hline & & $\mathbf{R}$ & W & $\mathbf{X}$ & $\mathbf{R}$ & $\mathbf{W}$ & $\mathbf{X}$ & $\mathbf{R}$ & W & $\mathbf{X}$ \\
\hline 1 & Dashboard & $\checkmark$ & & & & & & $\checkmark$ & & \\
\hline 2 & MAK & $\checkmark$ & $\checkmark$ & $\checkmark$ & & & & & & \\
\hline 2.1 & Tambah Data & $\checkmark$ & $\checkmark$ & & & & & & & \\
\hline
\end{tabular}


PETIR: Jurnal Pengkajian dan Penerapan Teknik Informatika Vol. 14, No. 1, Maret 2021, P-ISSN 1978-9262, E-ISSN 2655-5018 DOI: https://doi.org/10.33322/petir.v14i1.1021

\begin{tabular}{|l|l|c|c|c|c|c|c|c|c|c|}
\hline \multirow{2}{*}{ No } & \multicolumn{3}{c}{ Fitur } & \multicolumn{3}{c|}{ Asdep (A) } & \multicolumn{3}{c|}{ Staff (O) } & \multicolumn{3}{c|}{ Deputi(E) } \\
\hline 2.2 & Search & R & W & X & R & W & X & R & W & X \\
\hline 2.3 & Edit & $\checkmark$ & & & & & & & & \\
\hline 2.4 & Delete & $\checkmark$ & & $\checkmark$ & & & & & & \\
\hline 3 & Perencanaan Program & $\checkmark$ & & $\checkmark$ & & & & & & \\
\hline 3.1 & Tambah rencana & $\checkmark$ & $\checkmark$ & $\checkmark$ & $\checkmark$ & $\checkmark$ & $\checkmark$ & & & \\
\hline 3.2 & Ubah rencana & & & & & $\checkmark$ & $\checkmark$ & & & \\
\hline 3.3 & Hapus rencana & & & $\checkmark$ & & & $\checkmark$ & & & \\
\hline 3.4 & Persetujuan rencana & $\checkmark$ & & & $\checkmark$ & & & & $\checkmark$ & $\checkmark$ \\
\hline 3.5 & Cetak perencanaan & $\checkmark$ & & $\checkmark$ & & & & $\checkmark$ & & $\checkmark$ \\
\hline $\mathbf{4}$ & Penganggaran Program & $\checkmark$ & & & $\checkmark$ & & & $\checkmark$ & & \\
\hline 4.1 & Tambah rencana & & & & $\checkmark$ & $\checkmark$ & $\checkmark$ & $\checkmark$ & $\checkmark$ & $\checkmark$ \\
\hline 4.2 & Ubah rencana & & & & $\checkmark$ & $\checkmark$ & $\checkmark$ & & & \\
\hline 4.3 & Hapus rencana & & & $\checkmark$ & & & $\checkmark$ & & & \\
\hline 4.4 & Persetujuan rencana & $\checkmark$ & & & $\checkmark$ & & & & $\checkmark$ & $\checkmark$ \\
\hline 4.5 & Cetak perencanaan & $\checkmark$ & & $\checkmark$ & $\checkmark$ & & $\checkmark$ & $\checkmark$ & & $\checkmark$ \\
\hline $\mathbf{5}$ & Laporan Kegiatan & $\checkmark$ & $\checkmark$ & $\checkmark$ & $\checkmark$ & & $\checkmark$ & $\checkmark$ & & $\checkmark$ \\
\hline 5.1 & Cari Kegiatan & $\checkmark$ & & & $\checkmark$ & & & $\checkmark$ & & \\
\hline 5.2 & Isi Kegiatan & & & & $\checkmark$ & $\checkmark$ & $\checkmark$ & & & \\
\hline 5.2 .1 & Edit Kegiatan & & & & $\checkmark$ & $\checkmark$ & $\checkmark$ & & & \\
\hline 5.2 .2 & Simpan Kegiatan & & & & $\checkmark$ & $\checkmark$ & $\checkmark$ & & & \\
\hline 5.3 & Cetak Rekap Laporan & $\checkmark$ & & $\checkmark$ & & & & $\checkmark$ & & $\checkmark$ \\
\hline $\mathbf{6}$ & Monev & $\checkmark$ & & & $\checkmark$ & & & $\checkmark$ & & \\
\hline 6.1 & Monitoring & $\checkmark$ & $\checkmark$ & $\checkmark$ & $\checkmark$ & & & $\checkmark$ & & \\
\hline 6.2 & Evaluasi & $\checkmark$ & $\checkmark$ & $\checkmark$ & $\checkmark$ & $\checkmark$ & $\checkmark$ & $\checkmark$ & $\checkmark$ & $\checkmark$ \\
\hline 6.3 & Cetak Rekap Monev & $\checkmark$ & & $\checkmark$ & $\checkmark$ & & $\checkmark$ & $\checkmark$ & & $\checkmark$ \\
\hline
\end{tabular}

\subsection{Hasil Rancangan Aplikasi}

Berikut merupakan hasil dari rancangan CRUD matrix yang telah diimplementasikan pada aplikasi monitring perjalanan dinas.

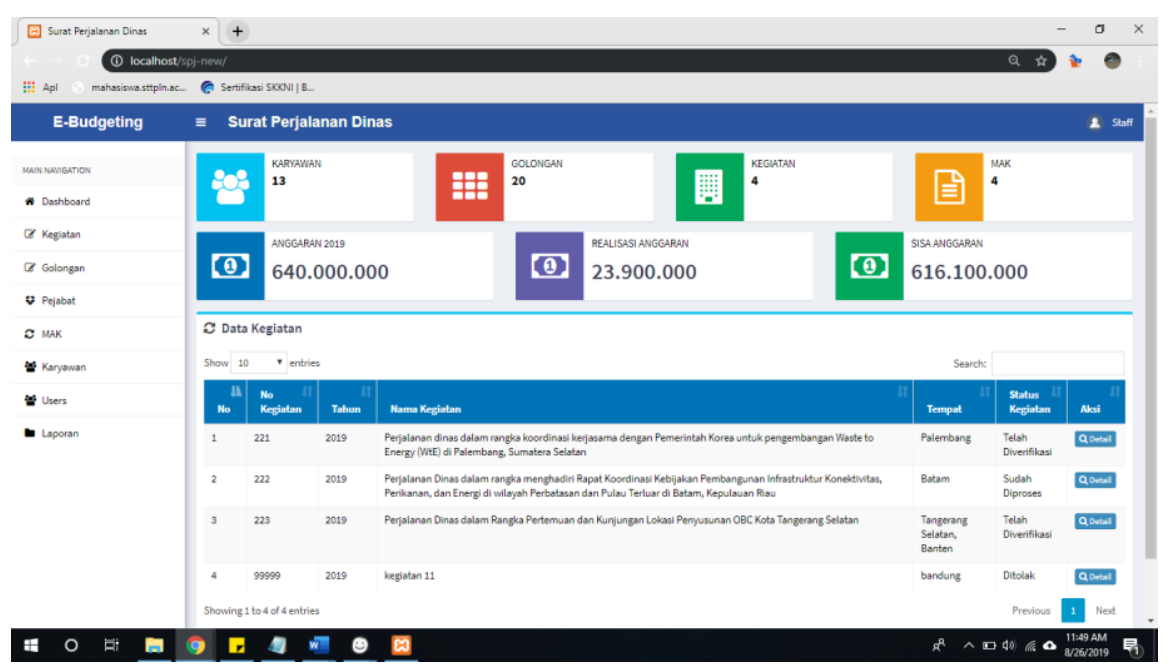

Gambar 5. Hasil Rancangan Modul Dashboard 
Pada gambar 5 merupakan hasil dari tampilan dari modul dashboard, dimana beberapa informasi kritis yang sangat diperlukan pada monitoring anggaran terlihat pada halaman utama aplikasi.

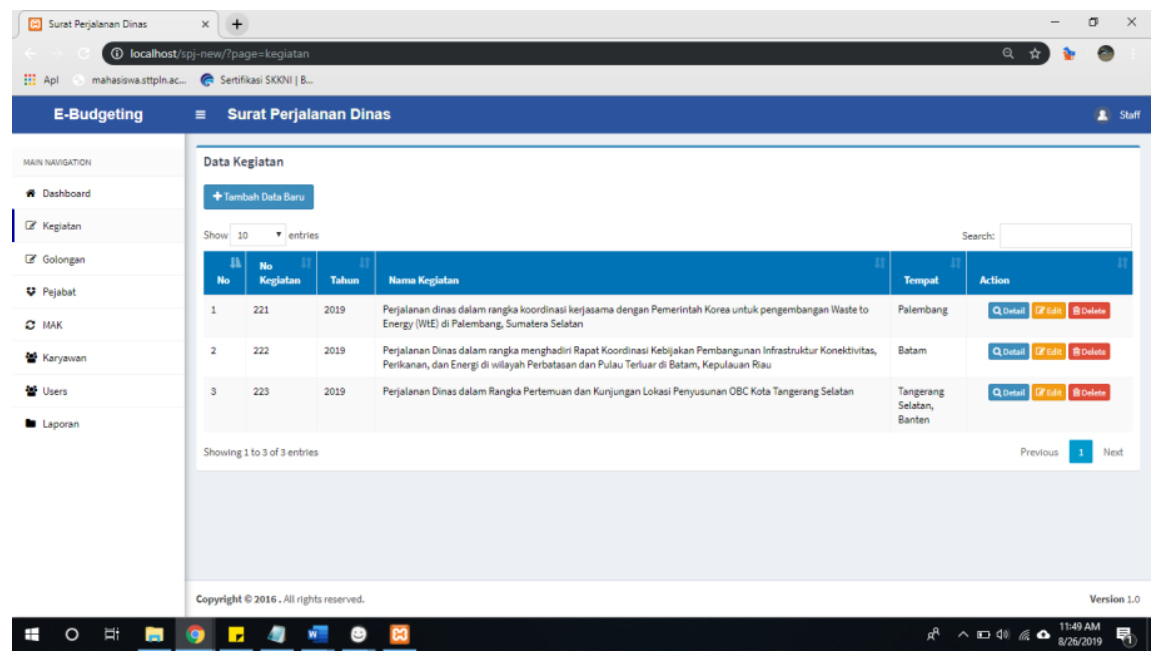

Gambar 6. Hasil Rancangan Modul Perencanaan Program

Pada gambar 6 kita dapat menambahkan data perencanaan program baru untuk kita anggarkan programmnya. Setelah dilakukan perencanaan keluar berupa produk surat tugas yang akan diketahui oleh masing-masing atasan dari pelaksana tugas dinas tersebut.

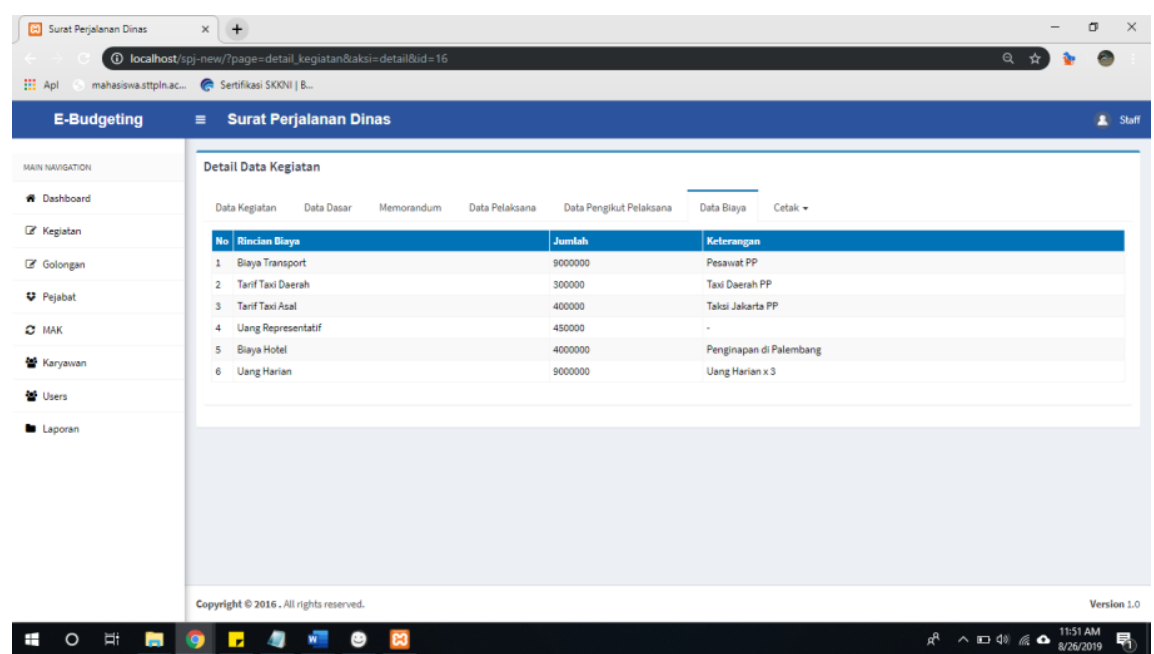

Gambar 7. Hasil Rancangan Penganggaran Program

Pada gambar 7 merupakan modul untuk melakukan penganggaran biaya perjalanan dinas dengan detail, hal ini akan berhubungan dengan monitoring dan evaluasi yang akan dilakukan setelah proses implementasi program. 


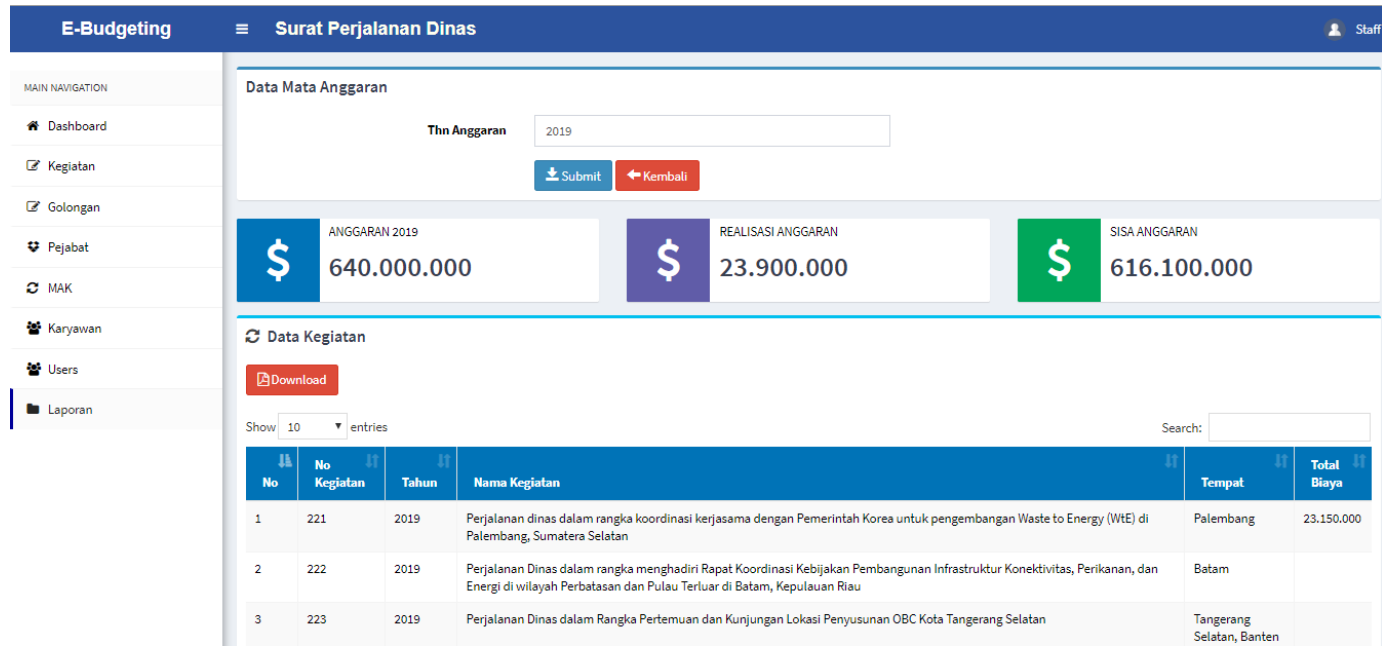

Gambar 8. Hasil Rancangan Laporan Legiatan

Pada gambar 8 kita akan melihat hasil dari implementasi yang dilakukan oleh pelaksana tugas dinas. Untuk dilakukan monitoring dan evaluasi terhadap anggaran yang dilakukan selama perjalanan dinas. Terlihat juga pada bagian atas aplikasi anggaran yang tersedia dan sisa dari anggaran. Untuk proses tahap monitoring dan evaluasi akan diperlihatkan detail dari anggaran yang direalisasikan.

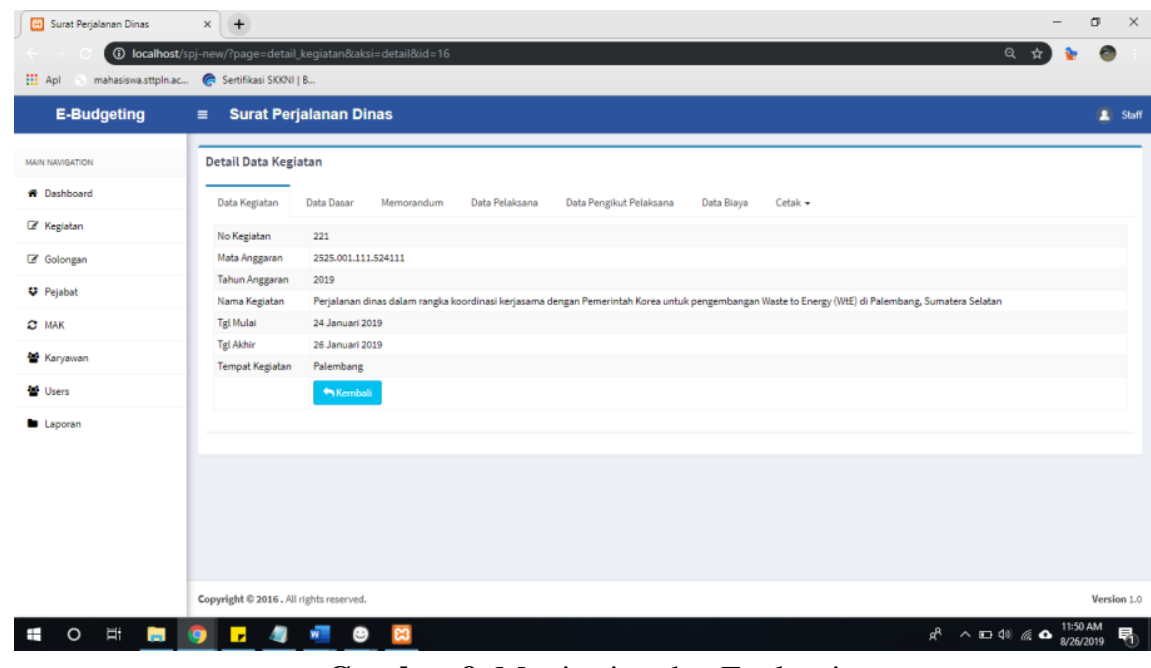

Gambar 9. Monitoring dan Evaluasi

Pada gambar 9 terilihat bagian detail dari implementasi program yang dilakukan oleh pelaksana tugas dinas. Dalam hal pelaksanaannya monitoring dan evaluasi dapat dilakukan secara virtual atau desk evaluasi mengikuti kebutuhan dari mitra bestari masing-masing pemangku kepentingan.

\subsection{Pembahasan}

Kerangka OBB yang dirancang ternyata ada beberapa hal yang tidak dapat dilakukan secara full terkomputerisasi. Pada dasarnya sebuat sistem informasi adalah sebuah wadah dimana untuk mengelola informasi. Pada pelaksanaanya para entitas masih sangat memiliki ruang untuk bereksplorasi mengenai proses bisnis lainnya terutama pada modul monitoring dan evaluasi serta modul kebijakan dan perbaikan. 


\section{KESIMPULAN DAN SARAN}

kerangka OBB dapat diimplementasikan kedalam sebuah aplikasi yang akan digunakan untuk melakukan pemantauan perjalanan dinas. Struktur pada OBB juga menyediakan informasi kepada pejabat pemberi perintah dalam memantau dan mengevaluasi proses dan hasil perjalanan dinas yang sedang atau selesai dilaksanakan. Selain itu pejabat pemberi perintah dapat memantau anggaran yang tersisa pada anggaran perjalanan dinas yang telah dianggarkan.

\section{DAFTAR PUSTAKA}

[1] Sedianingsih, Teori dan Praktik Administrasi Kesekretariatan. Surabaya: Prenada Media, 2010.

[2] Zarnelly, "SISTEM INFORMASI E-BUDGETING MENGGUNAKAN ( Studi Kasus : UIN SUSKA Riau )," J. Ilm. Rekayasa dan Manaj. Sist. Informasi, Vol. 3, No. 1, Februari 2017, Hal. 70-77 e-ISSN 2502-8995 p-ISSN 2460-8181, vol. 3, no. 1, pp. 70-77, 2017.

[3] H. Kamil and A. Lathifah S, "Rancang Bangun Sistem Informasi Realisasi Anggaran Kegiatan Berbasiskan Web dan Mobile pada Dinas Perhubungan Komunikasi dan Informatika Provinsi Sumatera Barat," J. Nas. Teknol. dan Sist. Inf., vol. 3, no. 1, pp. 177-186, 2017, doi: 10.25077/teknosi.v3i1.2017.177-186.

[4] E. A. K. Lestari, S. E. Anjarwani, and N. Agitha, "Rancang Bangun Sistem Informasi Surat Perintah Perjalanan Dinas Pada Sekretariat Daerah Provinsi Berbasis Web," J. Comput. Sci. Informatics Eng., vol. 2, no. 1, pp. 29-36, 2018, doi: 10.29303/jcosine.v2i1.68.

[5] Y. Ramadhani, "SISTEM INFORMASI MONITORING DAN EVALUASI PELAKSANAAN ANGGARAN PENDAPATAN DAN BELANJA DAERAH ( APBD ) PADA KANTOR DINAS PENDIDIKAN," vol. 2, pp. 42-51, 2019.

[6] Pemerintah Republik Indonesia, "Peraturan Pemerintah Nomor 12 Tahun 2019 tentang Pengelolaan Keuangan Daerah,” J. Media Huk., p. 184, 2019.

[7] Dimas Rizky Gunawan, "Penerapan Sistem E-Budgeting Terhadap Transparansi Dan Akuntabilitas Keuangan Publik (Studi Pada Pemerintah Kota Surabaya)," J. Chem. Inf. Model., vol. 53, no. 9, pp. 1689-1699, 2013, doi: 10.1017/CBO9781107415324.004.

[8] M. Munandar, Budgeting: Perencanaan Kerja, Pengkoordinasian Kerja, Pengawasan Kerja (Edisi 2). Yogyakarta: Universitas Gajah Mada, 2007.

[9] S. Atika, S. Harahap, and T. Taufik, "Pengaruh Perencanaan Anggaran, Pelaksanaan anggaran , Pencatatan Administrasi dan Kompetensi Sumber Daya Manusia Terhadap Tingkat Penyerapan Anggaran ( Studi Empiris pada OPD Kota Dumai )," vol. 13, no. 1, pp. 1-10, 2020.

[10] S. Rachmawati, T. Retnasari, and Sunarto, "Optimalisasi Sistem Informasi Perjalanan Dinas Dalam Meningkatkan Efisiensi Biaya Perusahaan,” J. Penelit. Tek. Inform., vol. 1, pp. 87-95, 2018.

[11] N. S. W. Treasury, "TPP18-09 Outcome Budgeting,” no. December, 2018.

[12] A. Torim, "A visual model of the CRUD matrix," Front. Artif. Intell. Appl., vol. 237, pp. 313320, 2012, doi: 10.3233/978-1-60750-992-9-313.

[13] M. of F. Malaysia, "Outcome Based Budgeting, an integrated approach to public sector performance management in malaysia," 2014. 